\title{
The Archives of Universal History
}

\section{Citation}

Rothschild, Emma. 2008. The archives of universal history. Journal of World History 19(3):

375-401.

\section{Published Version}

doi:10.1353/jwh.0.0016

\section{Permanent link}

http://nrs.harvard.edu/urn-3:HUL.InstRepos:4726590

\section{Terms of Use}

This article was downloaded from Harvard University's DASH repository, and is made available under the terms and conditions applicable to Other Posted Material, as set forth at http:// nrs.harvard.edu/urn-3:HUL.InstRepos:dash.current.terms-of-use\#LAA

\section{Share Your Story}

The Harvard community has made this article openly available.

Please share how this access benefits you. Submit a story.

Accessibility 


\title{
The Archives of Universal History*
}

\author{
EMMA ROTHSCHILD \\ Harvard University
}

E

VEN THE RECORDS of international conferences were the object, in I945, of large and unlikely hopes. The establishment of a "United Nations Archives," the staff of the National Archives of the United States wrote in a proposal of October 1945, would have an essential function in relation to the United Nations' own records and to the records of other international organizations. The archives could also serve as the repository for the far more extensive records that were described in the proposal as "clothed with an international interest," "vested with international interest," or "of International Concern and Importance." It could be the repository, even, of the continuity over time of the new institutions, in which "all nations have an immense stake," and thereby of "the fate of civilization itself." For the archives would "represent a cohesive factor of the sort that will make it harder for any such international organization to be split asunder": "Just as a

* This article draws in part on a paper, "Ideas and UN History," presented at the international symposium "6o Ans d'Histoire de l'UNESCO/6o Years of UNESCO's History," on I 7 November 2005. I am most grateful to many individuals for helpful discussions of the questions considered here, and in particular to Sunil Amrith, Jens Boel, Philipp Lehmann, Thant Myint-U, and Lisbet Rausing, and to Ike Achebe, Jeremy Adelman, Bernard Bailyn, Chris Bayly, Kathy Bushkin, David Cannadine, the late Ruth Cardozo, Bernhard Fulda, Victor Gray, Akira Iriye, Richard Jolly, Paul Kennedy, Melinda Kimble, Pierre Le Loarer, Catherine Merridale, Thandika Mkandawire, David Motadel, Holger Nehring, Hisashi Owada, David Reynolds, Glenda Sluga, Jonathan Steinberg, Julia Stephens, Barry Supple, Thomas Weiss, and Tim Wirth. I am also grateful to the Andrew W. Mellon Foundation for its support to the program on Exchanges of Economic and Political Ideas since I 750, at the Centre for History and Economics, University of Cambridge; and to the Rockefeller Foundation and the United Nations Foundation for their support of the Common Security Forum program at the Centre for History and Economics. 
national archival establishment, as the repository of a people's experience as a nation, has often in the past served as an effective symbol of nationalism, so a United Nations Archives would, as it comes to maturity, with a permanent building and extensive holdings, serve as a potent symbol of internationalism." 1

These vast expectations of the immediate postwar period were dismissed within a matter of months. The UN's Archives Section was established at Lake Success, New York, in I946, but "failed to develop into the great archival agency that [the US National Archives] envisioned." "2 More than sixty years later, it had no permanent building and very few holdings other than those of a portion of the UN secretariat's own records. There were forty-one distinct archives within the UN itself and the other international or intergovernmental organizations. ${ }^{3}$ The responsibility for the "archival whole," or for what the archivist of the United States described in I 946 as "man's archival heritage throughout the world"- "Should we not, therefore, think of all the archives of all the nations of the world, together with the archives of all international agencies of all sorts, as constituting the archives of mankind, the official record of human experience in organized living?" - was devolved to the new "Cultural Organization" of the UN. It was confided, in turn, to an International Council on Archives established at UNESCO, an institution of which a US official wrote in I95 I that "no United Nations agency has been more widely criticized," and whose principal failing, for the theologian Reinhold Niebuhr, was "that it gives wrong reasons for its important functions." ${ }^{4}$

1 The National Archives of the United States, "Proposal for the Establishment of a United Nations Archives" (Washington, D.C., October I945), typewritten document, CD 995.P69 I 945, US National Archives, 8 pp., pp. I, 4, 6, 7, 8. The document was described by the US archivist of the time as "processed in a considerable number of copies, but not published"; it was "drawn up by the Archivist, Dr. Solon J. Buck, and the Program Adviser, Oliver W. Holmes." Solon J. Buck, "The Archivist's 'One World," presidential address to the tenth annual meeting of the Society of American Archivists, delivered on 24 October I946, American Archivist Io, no. I (1947): 9-24, I3; and Robert Claus, "The United Nations Archive," Archivum 2 (I952): I I-I 5, I I.

2 Ernst Posner, "Solon Justus Buck and the National Archives" (I960), in Archives $\mathcal{E}$ the Public Interest: Selected Essays by Ernst Posner, ed. Ken Munden (Washington, D.C.: Public Affairs Press, I967), pp. I4I-I 47, I46; and Claus, "United Nations Archive," p. I I. 2007).

${ }^{3}$ See http://www.unesco.org/archives/sio/guide/index.html (accessed i9 October

${ }_{4}^{4}$ Buck, "Archivist's 'One World,” p. I 2; Reinhold Niebuhr, "The Theory and Practice of UNESCO," International Organization 4, no. I (1950): 3-I I, 5; and Walter R. Sharp, "The Role of UNESCO: A Critical Evaluation," Proceedings of the Academy of Political Science, 24, no. 2 (I95I): IOI-II4, II3. "The error of UNESCO," for Niebuhr, consisted "in its claim that its various forms of cultural cooperation are of immediate political significance in resolving overt conflicts in the world community." 
The proposal of October 1945 had become the latest in a sequence of unsuccessful schemes for a universal or world archive. It had something of the spirit, even, of the earliest and most awe-inspiring of the modern proposals, or the archive, to be built entirely in stone and iron, of which the foundation stone was laid near the Pont d'Iéna in Paris on I5 August I8I2, the birthday of the emperor Napoleon. The "authentic acts" so essential to historical understanding had been dispersed, hitherto, in monasteries, provinces, and kingdoms, Napoleon's minister of the interior declared at the foundation ceremony; the new "palais des archives" was to include the records of "the largest part of the eminently civilised world," and "the erection of this monument becomes itself one of the great events of history." ${ }^{5}$ The archive was to constitute the "general archives of the entire world." There was a printed catalogue of the entire collection of 266,766 cartons and boxes ("Algerina, Alsatica, Anglica ... Turcica, Veneta"), also published on the emperor's birthday; there was a tariff, in French, Italian, and German, of the prices to be charged for responding to the inquiries which were expected to be received from "families or individuals" in all parts of Europe. ${ }^{6}$

${ }^{5}$ Speech of M. de Montalivet, Minister of the Interior, on 15 August I8I2, Decree of 2 I March I8I2, in Henri Bordier, Les Archives de la France (Paris: Dumoulin, I855), pp. $27-28,393$. The premodern projects of a universal repository of archives are at least as old as the collection of the Assyrian King Assurbanipal, in Nineveh in the seventh century B.C., "amongst the most zealous collectors of manuscripts the world has yet known"; as old, even, as the "ancient Mesopotamian archival room" of more than a millennium earlier. See D. T. Potts, "Before Alexandria: Libraries in the Ancient Near East," in The Library of Alexandria: Centre of Learning in the Ancient World, ed. Roy Macleod, pp. I9-33 (London: I. B. Tauris, 2004), pp. 2 I , 25-26, 30. The National Archives of Mexico, which "was the first of its kind established in America, in I 789," was conceived of from the outset as a "General Archives." See Patricia Galeana, "Preserving Archives: The Mexican Experience" (r 999), available at http://old.ica.org/citra/citra.budapest. I999.eng/galeana.pdf. The project of accumulating the archives of different sovereignties was as old, in Europe, as the expansion of the French kings' "Trésor des Chartes" after I 27I; see [Robert-Henri Bautier], "Les Archives et le Droit International," in Direction des Archives de France, Les Archives dans la Vie Internationale: Actes de la Sixième Conférence Internationale de la Table Ronde des Archives, pp. 12-56 (Paris: Archives Nationales, I963), pp. I 2-I 5 .

6 Bordier, Les Archives de la France, p. ig, "Arrêté du 6 mai I 8 I 2" on the costs of research, pp. 393-394. The printed catalogue of the archives, Tableau systématique des Archives de l'Empire au I 5 aout I 8 I I (Paris: Baudouin, I8I I ), was associated with the auspicious date of Napoleon's birthday in the previous year. Pierre Claude François Daunou's manuscript and corrected proofs, which are in the Houghton Library in Harvard University, bear the characteristic marks of extreme haste; a second proof to be sent within the day, and a third proof "the soonest possible." They also indicate hesitation; "division germanique" is changed to "division allemande," and "relations avec les diverses puissance de l'Europe" to "relations avec les puissances étrangères" (this is in the section dealing with the political archives of the Holy Roman Empire, the Algerina to Veneta series). Manuscript of the "Tableau systématique," Houghton Library, Fr 57.I 2.9, p. I 7. 
The archive of 18 I $_{2}$ was the product of plunder on a scale that was described by an archivist of the second empire as "grandiose," "gigantic," or "colossal": five hundred carriages with the papers of the royal archives of Simancas in Spain; 3,I39 cases brought from Vienna, with oriental manuscripts and codices; I 2, I 47 cases brought from Rome, in carts so large that they were drawn by four mules and six cattle; the twenty-two papyrus charters from the walls of the great hall of the Vatican Archives, destined to be the "ornament and in some sense the frontispiece of His Majesty's immense depository of archives." ${ }^{7}$ It all amounted, in the end, to almost nothing. Napoleon was already in a bivouac in Krasnoï in Russia in August I 8 12, and the new building rose to a height of no more than two meters, before it was eventually abandoned in I 816. Almost all the cases were returned (with the exception of some of the documents from the pontifical archives, which were said to have been sold to various grocery shops in Paris, in order to cover the costs of restitution). ${ }^{8}$

But the idea of a universal archive, suited to or isomorphic with the new universal society of the times and the new universal history, has been far more enduring. Napoleon himself, in Saint Helena, described the new Europe of his imagination as a place of universal enlightenment, "antinational," with a congress like that of the United States. Its relationships to the rest of the world were to be no longer colonial, but ones of "entire freedom of universal exchange." He became interested, in exile, in the classification of "our little archives" and instructed his few courtiers to transcribe them. He was said, even, to have hoped to devote himself in retirement to the writing of a new and disinterested kind of history, based on "the archives of our external relations." 9

The archive of I945, or the American project of a universal archive, was the product of a similarly grandiose moment. The new "United Nations Organization" of I944-I945 was to a striking extent the

${ }^{7}$ Marquis de Laborde, Les Archives de la France: Leurs vicissitudes pendant la Révolution, leur régéneration sous l'Empire (Paris: Renouard, I 867), pp. I88-189, 195-197, 199-200; undated letter about the papyrus charters from Daunou, the first director of the archives of the empire, pp. 423-424; Hanns Schlitter, "Die Zurückstellung der von den Franzosen im Jahre I 809 aus Wien entführten Archive, Bibliotheken und Kunstsammlungen," Mittheilungen des Instituts für Österreichische Geschichtsforschung, vol. 22 (I 90I), I08-I 22.

${ }^{8}$ Bordier, Les Archives de la France, pp. I 9-20, 28; Laborde, Les Archives de la France, p. 426; letter of I 5 August I 8 I 2 to the Duc de Bassano, dated "Bivouac de Boyarintsova, entre Krasnoï et Siniaki, " in Correspondance de Napoléon Ier (Paris: Imprimerie Impériale, I 868), 24:I56. Napoleon was at the time on the way to Moscow; Krasnoï was the scene, exactly three months later, of one of the climactic defeats of his long retreat.

9 Comte de Las Cases, Le Mémorial de Sainte-Hélène, ed. Joël Schmidt (Paris: Éditions du Seuil, I968), pp. 808, I I3 I, I 290-I 29I, I462, I 545. 
expression of a distinctively North American ideology of international and even "antinational" institutions, and of internationalism as itself distinctively American. The "activities and programs of the United States Government" were described by the National Archives as to "an increasing extent" being "carried on through international agencies." 10 The UN Charter was presented "to the American people as almost holy writ and with the evangelical enthusiasm of a major advertising campaign," in the expression of Dean Acheson, Truman's secretary of state; "the General Assembly appeared as the Town Meeting of the World." 11 A British diplomat conveyed the spirit of the times in an account of a conversation in March I 945 about the establishment of the new UN secretariat. "The Americans had contemplated appointing Americans to all the key positions but had thought that these might be assisted by a number of secretaries (say I 5 ) drawn from the various nations," Gladwyn Jebb wrote; when he expressed the British government's "grave doubts" about the possibility of an international secretariat, "Americans replied that from their point of view there was of course much to be said for an all-American secretariat, but they did not want to give the impression that they were running everything." 12

The National Archives of the United States, which was itself a new organization, with a permanent building of which the foundation stone had been laid as recently as I933, had an interesting and complicated relationship to this internationalist Americanism of the new UN. The only detailed published account of the October I945 proposal was in an article by Solon Buck, the archivist of the United States until I 948 (and a scholar of the agrarian protest movements of the I89os), which was published in 1947 under the evocative title "The Archivist's 'One World."' 13 The first professional "Acting Archivist of the United Nations" was a member of the staff of the US National Archives. ${ }^{14}$ Even the organization of the US National Archives was international, in part through the influence of Ernst Posner, a former archivist in the

10 Thirteenth Annual Report of the Archivist of the United States 1946-1947 (Washington, D.C., I947), p. 26.

${ }_{11}$ Dean Acheson, Present at the Creation: My Years at the State Department (New York: Norton, I969), pp. I I I-I I 2.

12 Telegram number 1798 of I9 March 1945 from Gladwyn Jebb to the Earl of Halifax, marked "This telegram is of particular secrecy cypher," in the National Archives (United Kingdom) (TNA), BTI I $/ 2540$, item I I, p. 3.

${ }_{13}$ On the publishing history of Wendell Willkie's One World, see Paul Kennedy, The Parliament of Man: The Past, Present, and Future of the United Nations (New York: Random House, 2006), pp. 25, 297, n. I 5.

${ }^{14}$ Buck, "Archivist's 'One World," p. I6. 
Geheimes Staatsarchiv in Berlin, editor of Acta Borussica and an expert on the international politics of archives, who came to the United States via Sweden in I939. But Posner never became a permanent employee of the National Archives; "How many aliens have you got working for you, sir?" Solon Buck had been asked at a Senate hearing in $\mathrm{I} 944 \cdot{ }^{15}$ By I950, the National Archives had itself been relegated to a different and less independent position as a part of the General Services Administration, associated with "government buildings, supplies, repairs, and transportation." 16

The transient moment of archival internationalism came to a slow end over the course of the I950s, in a succession of councils and commissions, mostly under the auspices of UNESCO. But the two deep questions that had been raised implicitly or explicitly in the proposal of October I945-about what it is for an archive to be international, and why archives are of importance to international institutions-were a continuing preoccupation of UNESCO and, intermittently, of other $\mathrm{UN}$ agencies. They are questions that are of interest still to the new or renewed enterprise of a history of the United Nations.

The idea of an international archive is not entirely straightforward, as the metaphorical language of the 1945 proposal indicates, with its records clothed and vested in international concern. ${ }^{17}$ There are at least three main respects in which archives are international, having to do with the international interest in archives anywhere, including the archives of local or particular societies; the archives of international or transnational or long-distance connections; and the archives of international institutions. Each of these was the subject of extended dispute within UNESCO.

The first sense in which archives are international, that they are archives in which distant persons are interested, was captured in an

15 Paul Lewinson, "Introduction: The Two Lives of Ernst Posner," in Munden, Archives $\mathcal{E}$ the Public Interest, pp. 7-19, 9, I6; and Hartmut Lehmann and James J. Sheehan, eds., An Interrupted Past: German-Speaking Refugee Historians in the United States after I 933 (Cambridge: Cambridge University Press, I991), pp. 75, I I9. On the "Posner affair," see Donald R. McCoy, The National Archives: America's Ministry of Documents 1934-1968 (Chapel Hill: University of North Carolina Press, I978), pp. I4 I-I 44.

${ }^{16}$ Lester J. Cappon, "The National Archives and the Historical Profession," Journal of Southern History 35, no. 4 (I969): 477-499, 489. The National Archives were restored to the status of an independent agency by the National Archives and Records Administration Act of 1984 ; see http://www.archives.gov/about/history/anniversary/nara-act.pdf.

17 "'All emblematic things are properly Clothes, thought-woven or hand-woven... What is it all but Metaphors." Thomas Carlyle, Sartor Resartus: The Life and Opinions of Herr Teufelsdröckh in Three Books ( I 834), ed. Rodger L. Tarr (Berkeley: University of California Press, 2000), pp. 55-56. 
imposing phrase of the October I 945 proposal about the "world's cultural heritage," of which the "deterioration will be a loss to civilization and not merely to the country that happens to be their custodian." ${ }^{18}$ It was this somber responsibility that was devolved to the International Council on Archives established at UNESCO in 1948, whose initial constitution included the resolution to "promote all possible measures for the preservation, protection and defense against all hazards of the archival heritage of mankind." ${ }^{19}$ The director of UNESCO of the time, Jaime Torrès-Bodet, welcomed the council by recalling the importance of the archivists of Mexico to his own earlier political work. "It would be wrong," he said, to "see in the arrangement of your files or in your collections of microfilms, immense cemeteries where the experiences, the adventures, the risks and the dramas of society are buried for ever." Archives were rather the condition for the "continuity of the human conscience" and of the possibility of good government; they contained the "instructive traces of life." 20

The tone of the early discussions was by no means uniformly uplifting, and the multiple divisions of the times were amply expressed in the discussions of archives. There was the supposedly restrictive French conception of the organization ("a sort of United Nations Ministry of Education") versus the "much more ambitious approach" of the United States ("'peoples speaking to peoples,' through the new techniques of mass communication"), at a time of what was described in I95I as a "deeply rooted fear of American cultural imperialism." 21 ("While we aren't considered as un-peace-loving as the Russians, a peace-loving nature is not thought to be one of our prime assets as people," an American specialist on public opinion lamented in the UNESCO Courier in $1952 .{ }^{22}$ ) There was a partition of the world: a vice-president of the Council on Archives from the "western hemisphere" (in this case the United States), and a vice-president from the "eastern hemisphere" (in this case the United Kingdom). Charles Braibant of the Archives de France depicted the pathos and the bathos of the scene in the first issue of Archivum, the journal of archival internationalism. Archivists, he wrote in $195 \mathrm{I}$, were individuals who were used to working in condi-

18 "Proposal for the Establishment of a United Nations Archives," p. 7 .

19 UNESCO/LBA/ARC/2. (Rev.2) Paris, 5 January 1949, in TNA, PROr/998.

20 "L'Assemblée Constituante du Conseil International des Archives, " message of 2 I August 1950, Archivum I (195I): 26.

21 Sharp, "The Role of UNESCO," pp. I02, I I 3.

22 Elmo C. Wilson, "How Europeans Feel about Americans," UNESCO Courier, April I952, p. I4, available at http://unesdoc.unesco.org/ulis/search_form.html. 
tions of difficulty and poverty and being thought of as "passive warehousemen of history." But "fraternal links between the archivists of all countries" could contribute to "curing the troubled and uncertain world of today." 23

For Solon Buck of the US National Archives, the work at UNESCO was a matter, even, of worldwide democracy. "His was a profile in archival courage," Ernst Posner wrote in I960: he believed not only that the Council on Archives should have "a more democratic organization" (it should be "a professional organization of archivists" rather than "a federation of national archives") but also that there should be "a democratization of the archival reference service" - a very large-scale microfilming and duplication of manuscripts, to be made "readily and equally available to the scholars of all countries." ${ }^{24}$ UNESCO had only very limited resources with which to respond to Buck's imposing exhortation that "[s]cholarship that feeds upon the archival resources of a single country cannot be otherwise than one-sided and nationalistic. The only antidotes are freedom of access to the originals in whatever country they may happen to be and the making and exchange of photographic facsimiles." 25

The "gigantic plans for duplication of all important source materials in all accessible countries" of 1952 were never realized. ${ }^{26}$ But access to, or at least information about archives and other historical sources was one of the institution's continuing concerns, especially (and for some member states, surprisingly) in relation to Africa: the three-volume work by S. A. I. Tirmizi, a former director of the National Archives of India, called Indian Sources for African History, which could inspire multiple $\mathrm{PhD}$ dissertations; Sources of the History of Africa, Asia and Oceania in Yugoslavia; Guida delle fonti per la storia dell' Africa a Sud del Sahara negli archivi della Santa Sede. ${ }^{27}$ UNESCO's "mobile microfilm unit"

${ }^{23}$ Charles Braibant, "Archivum," Archivum I (195I): 3-4.

${ }^{24}$ Posner, "The National Archives and the Archival Theorist" (I954), in Munden, Archives $\mathcal{B}$ the Public Interest, pp. I3I-I40, I35; "Solon Justus Buck and the National Archives," pp. I46-I 47; Buck, "Archivist's 'One World,” p. I9; and see Cappon, "National Archives," p. 485. The reference to the profile of archival courage, in a paper which was originally presented as a talk in the summer of I960, was again an evocation of US politics; presidential candidate John F. Kennedy's Profiles in Courage.

25 Buck, “Archivist's 'One World,” p. I 7.

${ }^{26}$ Report of Lester K. Born, "Historical News," American Historical Review 57, no. 3 (1952): 795-850, 82 I-822.

${ }_{27}$ A British official grumbled in I949, in relation to proposed work on African cosmology, about the "familiar and unpleasant suggestion that studies of the kind proposed are peculiar to non-self-governing territories." Memorandum of 28 February I 949 from A. M. Peck to Mr. Ward, TNA, CO927/83/3. 
started work in Paraguay, led by an eminent paleographer of medieval Mallorca, and proceeded in I957 to Panama, El Salvador, Honduras, the Dominican Republic (where it filmed I 56,000 pages of documents, including the archives of the Cathedral of Santo Domingo), Barbados, and Peru. ${ }^{28}$ There were plans in 1960 for an "instituto tropical de patología del libro," to be established in Brazil, with a mission to preserve books and manuscripts from the ravages of insects, fungus, and bacteria, and, in 1971, for the microfilming of thousands of manuscripts in private collections in Yemen, "one of the most important missing links in the transmission of Greek culture to the Islamic." ${ }^{29}$

The second sense of international archives, that they are the archives of international or transnational or long-distance connections, was closely related. There are archives and memories that are of international interest, and that are not at all international, even in the "world threatened by monotony and uniformity" that Claude Lévi-Strauss described in Race et Histoire, published in the collective volume that is in many respects the high point of UNESCO's scholarly work Le racisme devant la science of $1960 .{ }^{30}$ There are archives, in turn, that are of international interest precisely because they are so uninternational, or so evocative of a lost and ununified world. But the history of connections has been of particular interest to individuals in distant locations and poses particular historical difficulties. I use the awkward expression "long-distance" because the adjectives "international" and "transnational" - which refer, respectively, to the relations between nations, in the sense of diplomacy, war, negotiation, or law, and relations across nations, in the sense of the multitude of other connections between individuals and groups in different nations, whether of migration, commerce, investment, culture, travel, science, infection, or romance-do not convey the extent of the connections

28 "Activités de l'UNESCO dans le Domaine des Archives," in Les Archives dans la Vie Internationale, pp. I I2-I I6, I I2-I I3; Francisco Sevillano Colom, "Lista Del Contenido de los Volúmenes Microfilmados del Archivo Nacional de Asunción," Hispanic American Historical Review 38, no. I. (I958): 60-I 20.

${ }^{29}$ Records of the General Conference, Eleventh Session (UNESCO, I960), p. 54, available at http://unesdoc.unesco.org/images/oori/oori45/II4583e.pdf; and Y-Ibish and M. Al-Ghul, Yemen Arab Republic: Evaluation of Ancient Books and Manuscripts, September I97 I (UNESCO, I972), p. 5, available at http://unesdoc.unesco.org/images/oooo/ooooo8/ 000865 eo.pdf. The preservation and filming of the manuscripts is described at http://www .unesco.org/webworld/mdm/visite/sanaa/en/presentr.html.

30 Claude Lévi-Strauss, "Race et histoire," in Le racisme devant la science (Paris: UNESCO/ Gallimard, I960), pp. 24I-28I, 280. 
between societies. ${ }^{31}$ Lévi-Strauss described Africa as the "melting pot culturel de l'Ancien Monde," and Timbuktu, which has been another of UNESCO's preoccupations, was a location on routes of commercial, religious, and cultural exchange that extended from Isphahan to the Atlantic. ${ }^{32}$ These kinds of exchange were not "international," and they were "transnational" only in that they can be located in the atlases of long-subsequent nations.

UNESCO has had an intimate relationship, throughout its existence, to the multiple connections that are the subject of transnational history. Its own origins, as Akira Iriye has shown, are to be found not only in the Committee on Intellectual Cooperation of the League of Nations but also in the theories of these connections - and of their consquences for universal society-of the earlier twentieth century. ${ }^{33}$ It was a reflection of the confidence that Leonard Woolf identified in I9I6, in respect to the "extraordinary and novel spectacle" of international voluntary associations, and of the "internationalizing of laws, science, customs, thought, industry, commerce, and society," and the reflection, too, of the "mortification and ... painful disillusionment" that Freud described a year earlier, the loss of the late nineteenthcentury expectation "that the extensive community of interests established by commerce and production would constitute the germ of ... a compulsion" toward morality, the sense of being "helpless in a world that has grown strange." 34

There is a sense in which the world of long-distance connections is intensely productive of evidence, including the sort of evidence that is so important to historians of transnational relationships. Individuals who are far away from their families write letters (if they can, or are permitted to). Associations are dependent on correspondence. Commerce and investment require records. Commodities and individuals

31 On global and transnational history, see Chris Bayly, contribution to "AHR Conversation: On Transnational History," American Historical Review I I I, no. 5 (2006), available at http://www.historycooperative.org.

${ }^{32}$ Lévi-Strauss, "Race et histoire," p. 262. UNESCO's continuing work, within the program "The Memory of the World," on the historical archives of Timbuktu, is an impressive illustration. See http://www.unesco.org/webworld/mdm/visite/sommaire.html and http:// www.bl.uk/about/policies/endangeredarch/threatweblinks.html.

33 Akira Iriye, Cultural Internationalism and World Order (Baltimore: Johns Hopkins University Press, 1997).

${ }^{34}$ L. S. Woolf, International Government (New York, I916), pp. 152, I70; Sigmund Freud, "Thoughts for the Times on War and Death" (1915), in Freud, The Standard Edition, ed. James Strachey (London: Hogarth Press, I957), I 4:280, 285, 288; and see Emma Rothschild, "What Is Security?" Daedalus I 24, no. 3 (I 995$)$ ) 53-98. 
are transcribed when they cross the frontiers of nations. The commemorations of large-scale migrations are sites of memory without a location. ${ }^{35}$ But this evidence is also fragile. Individuals wait for letters that do not arrive; they move on and leave their papers behind; the associations dwindle away and the investment ventures fail. Even the records of frontiers and ports are among the more marginal holdings, often, of national archives. This, too, was a preoccupation of early UNESCO officials, as in the I949 report on migration (and information about migration), which the British Colonial Office found some difficulty in classifying: "I think this may be of interest to your Department," one official wrote in I948; "It certainly is not 'Empire Settlement." 36

"All have finally felt that only History could place upon the already fruitful work of UNESCO the crown of hope for which it is gathering the flowers and the leaves, one by one," Lucien Febvre (or his less than eloquent amanuensis) wrote in a summary of the early UNESCO conferences in Mexico, Beirut, and Florence. ${ }^{37}$ This transcendent history was to be an epic, in turn, of the "global interdependence of peoples" (albeit under the direction of an editorial committee in which "are represented the cultures of Asia, Europe and America" and a working group consisting of "a Frenchman, an Italian, an Englishman, a Swiss, a Syrian, a Hindu, a Mexican, a North American, and a Brazilian"). ${ }^{38}$ Lévi-Strauss, in Race et Histoire, repudiated the notion of "peuples sans histoire," and discerned in the "coalition" or "collaboration" of cultures the possibility of a world civilization that was also a civilization of

35 See David Blackbourn, "Das Kaiserreich transnational. Eine Skizze," in Das Kaiserreich transnational: Deutschland in der Welt I87I-1914, ed. Sebastian Conrad and Jürgen Osterhammel (Göttingen, 2004); and Loretta Kim (Harvard University), forthcoming work on the commemoration of the involuntary migration of the Sibe people from Manchuria to Xinjiang in the Qing period.

${ }^{36}$ Note of 12 June 1948 from D. G. Hallett to Mr. Roberts, in TNA, CO537/2567, 3r. The question of information about migration was of much interest, as in the recommendation, heavily marked by the British officials, that "migration between home countries and colonies should be the subject of statistics analogous to international series," and in a summary, by R. C. Cade; "This calls for a regular supply of information about the needs of the receiving countries, the types, abilities, etc. of potential emigrants, together with technical advice and formulae for regulating the departure and admission of migrants." UNESCO Report on Migration, TNA, CO537/2567, 5v, I $30 \mathrm{v}$.

37 Lucien Febvre, "Foreword," in Cahiers d'Histoire Mondiale/Journal of World History/ Cuadernos de Historia Mundial I, no. I ( 1953): 6-9, 7; and see Sunil Amrith, paper presented at the international symposium "6o Ans d'Histoire de l'UNESCO/6o years of UNESCO's History," on 18 November 2005, and Sunil Amrith and Glenda Sluga, "New Histories of the UN," Journal of World History I 9, no. 3 (2008).

38 "Textes Officiels," Cahiers d'Histoire Mondiale I, no. I (I953): 205, 208, 22 I. 
tolerance-a prospect that imposed "heavy responsibilities" on "international institutions." 39

The third sense of international archives and international memory, to do with the archives of international organizations, is the least romantic. The International Council on Archives, in I952, presented a grandiose view: the evocation of a past in which archives had "not emerged from the local or national phase," and of international "organisms" whose role was ever more "primordial." But it also described entirely new versions of old problems: Conservation, but where? Classification, but how? Inventories, but whose? Public access, but with what "precautions"? 40 The archives of earlier international organizations, a member of the staff of the US National Archives wrote in October 1944, were "both inadequate and unsatisfactory," and "this lack of information is fairly universal." ${ }^{11}$ Some international records "seem to have disappeared," according to the US proposal of October I945, and others "have been broken up or scattered." ${ }^{42}$ The new Archives Section of the United Nations had inherited the records of "defunct international organizations," dating back to I897. It had custody of sound recordings, photographs, and "motion picture films." It had documents in the working languages of the UN, and in Czech, Slovenian, Arabic, Korean, and Portuguese, while "Secretariat groups are accumulating and creating archives in such far-flung areas as Cuba, Greece, Indonesia, Kashmir, Korea, and Palestine.” 43

It was these international and administrative archives that were at the heart of the proposal of October 1945 and in respect of which the postwar initiatives were least successful. The forty-one archives of international organizations are now the "agencies" of 192 sovereign (or member) states and seventeen unsovereign entities, of six "principal UN organs" and eighty-six programs, funds, commissions, offices,

${ }^{39}$ Lévi-Strauss, "Race et histoire," pp. 253, 272, 277, 279.

40 "Les organismes internationaux et leurs archives," Archivum 2 (1952): 9.

${ }^{41}$ In the polite expression of the US proposal of October 1945, "it is believed that there is room for improvement in the documentation practices of international agencies." "Proposal for the Establishment of a United Nations Archives," p. 6; Carl L. Lokke, "A Sketch of the Interallied Organizations of the First World War period and their records," American Archivist 7, no. 4 (I944): 225-235, 226, 234.

42 "The records of many interallied economic and scientific agencies seem to have disappeared ... "the records of other international bodies of the period have been broken up or scattered." "Proposal for the Establishment of a United Nations Archives," p. 2.

${ }_{43}$ Claus, "United Nations Archive," pp. I I, I 2, I 4. 
institutes, and "other UN entities." ${ }^{4}$ They are connected, still, within the International Council on Archives that was established with such large expectations in 1948. But they are not the sorts of archives that have inspired the sentiment of being able to "touch the real world" that Arlette Farge described so beautifully in Le Goût de l'Archive, the archival sublime. ${ }^{45}$ They are full, for one thing, of the cyclostyled records of committees and conferences, somewhat dispiritingly known by the technical term "grey literature." 46 The US National Archives proposal of October I 945 "went practically unnoticed," the archivist of the UN concluded in a paper prepared for an international meeting of archivists in Warsaw in I961, and he added that "as regards his official status," his post was "ranked three or four grades below that of Director of the Library." 47

The "historical aspect is at risk of being suffocated by the concern for immediate uses," the secretary of the archivists' journal Archivum wrote in a paper for the same meeting, and the use of the "microfilm of substitution is enough to make an archivist and historian shudder." There were "pure and simple liquidations," and the situation was particularly dire in respect to international agencies or commissions that had themselves been dissolved: the destruction, for example, of many of the papers of the UN mandate in Palestine, of the UN Relief and Rehabilitation Administration (UNRRA), and of the International Refugee Organization. ${ }^{48}$ There were "at present I,200 non-governmental organizations (NGO's) in the world," the director of the Polish State Archives observed, which were "an essential aspect of contemporary history" and whose archives were "disquieting." For the secretary

${ }^{44}$ See http://www.unesco.org/archives/sio/guide/index.html, http://www.un.org/ members/intergovorg.shtml, and http://www.un.org/aboutun/chartpdf/unsyschart.pdf, accessed on 19 October 2007.

${ }^{45}$ Arlette Farge, Le Goût de l'Archive (Paris: Éditions du Seuil, I989), p. I 8.

46 The initial archive of the I 945 San Francisco conference consisted of "all official Conference documents boxed in quantities of two hundred copies of each document in English," with more copies in French, Spanish, Russian, and Chinese; by i 947 , "about one-half" of the staff of the UN Archives was "engaged almost exclusively in the receipt, registration, filing, and servicing of mimeographed documents." William J. Bruce, "The San Francisco UNCIO Documents," American Archivist 9, no. I ( 1946): 6-16, 6; Robert Claus, "The Archives Program of the United Nations," American Archivist I I, no. 3 (1948): 195-202, I97.

${ }^{47}$ Marian Stopar-Babsek, "Establishment and Organization of United Nations Archives," in Les Archives dans la Vie Internationale, pp. 85-102, 87, 92.

48 [Robert-Henri Bautier], "Les Archives et les Organisations Internationales et Intergouvernementales," in Les Archives dans la Vie Internationale, pp. 76-82, 77-78. 
of Archivum, "a concrete solution would be to place the old archives of the UN," as well as "the archives of dissolved archives and eventually of NGO's," in a common depository of historical archives; "this is to go back to the idea of Dr Solon Buck in 1945." 49

"The dignity of source materials of history," Ernst Posner wrote in I942, had in the course of the twentieth century been "extended to an ever widening scope of documents." 50 This process of extension has continued ever since, and archival holdings, like historical memory, exist in multiple dimensions, virtual and spatial. But even the most conventional procedures of disposal, classification, and declassification, which are important to all archives, were particularly complex for international organizations, with their juxtaposition of languages and political morphologies (their organs and funds and entities), their blue flags and blue helmets and black box flight recorders. The records of UN missions, officials, employees under contract, mandates, conferences, and offices "in the field" were widely dispersed. ${ }^{51}$ In respect to the new universe of historical sources-images, artifacts, diaries, recordings, and oral histories, in multiple languages and multiple media-the international archives faced even more daunting difficulties. There were oral histories of soldiers who took part in international peacekeeping missions, and they could be "accessed" through the office of the Nigerian legion in Enugu, with "no functioning telephones, e-mail, fax facilities or internet." 52

${ }^{49}$ Report of the Fourth Working Session, in Les Archives dans la Vie Internationale, pp. I43-I45, I43-I44; Bautier, "Les Archives et les Organisations Internationales," p. 79.

50 Posner, "Effects of Changes of Sovereignty on Archives," in Munden, Archives $\mathcal{E}$ the Public Interest, pp. I68-I 8I, I 74 .

${ }^{51}$ Even the records of the most established of public officials posed redoutable difficulties in the new circumstances of international interdependence, as one of the US archivists wrote in I944; the traces of "Sir Maurice (now Lord) Hankey," for example, who "attended no fewer than 488 international meetings between I9I4 and I920." Lokke, "Sketch," p. 225. Hankey was an expert on cabinet minutes and official secrets in the I92os, whose own papers are now to be found in no fewer than thirty-eight different repositories. See National Register of Archives (United Kingdom), http://www.nationalarchives.gov.uk/nra/ searches/pidocs.asp?P=PI 2902; and John F. Naylor, "Hankey, Maurice Pascal Alers," Oxford Dictionary of National Biography, http://www.oxforddnb.com/view/article/33683, accessed I9 October 2007.

52 IkeAchebe, "OralHistoryonUNPeacekeepingOperations:TheNigeriaLegion,"http:// www-histecon.kings.cam.ac.uk/internationalhistory/documents/nigeria_oralhistory.doc. The Centre for History and Economics at King's College, Cambridge, has for some years had a tiny project on international and $\mathrm{UN}$ archives, which has identified interesting sources in and at the margins of the UN's own archival holdings: in Sunil Amrith's research on the diaries of officials involved in public health campaigns in Asia, Holger Nehring's investigation of UNESCO and UNICEF in German history, and Ike Achebe's investigation of Nigerian 
The archives of the UN have in these circumstances been relatively little used by historians and other scholars; of the several million articles in the English language JSTOR database, only twenty-nine refer to "United Nations Archives." (There are I6,523 articles, by contrast, that refer to "National Archives," and io,977 to "Public Record Office," the old name of the National Archives in the United Kingdom. $)^{53}$ They are unromantic, in the sense of the drama of national history, as expressed by US president Herbert Hoover, when he laid the cornerstone of the National Archives building in Washington, D.C., in February 1933, in words now engraved on the wall: "The romance of our history will have living habitation here in the writings of statesmen, soldiers, and all the others, both men and women, who have built the great structure of our national life." ${ }^{54}$

It is these grey, unromantic, international archives that are so interesting, all the same, in relation to the other deep question of October 1945, about why archives are of importance to international institutions. The idea of a gigantic United Nations Archive, a palace of internationalism and microfilms, is almost as implausible, now, as Napoleon's monument to monuments of I8I2. Even the archives of nations have only a faded relationship to the romances of national life, and to the cohesiveness of national institutions.

But the unpoetic objectives of the I940s and I950s, about the conservation of international records, are still important. The most familiar reason is that archives and accessible records are essential to the effectiveness of any organization, national or international. In the delicate expression of Napoleon's minister of the interior, "Without authentic acts . . . the lofty lessons of experience are lost for nations and for genius itself, when it is called upon to rule." ${ }^{55}$ The conflicts over archives in the early modern period were a competition for titles of sov-

soldiers who had served in peace-keeping forces in the Congo. But the project has also come across real difficulties, from empty folders to the head of a small UN agency who found part of the archives of the agency stored in the basement beneath the cleaning fluid. See www.internationalhistory.org; on German archives, see Holger Nehring, "UN Sources concerning Germany: A Guide to Archives and Research," http://www-histecon.kings.cam .ac.uk/internationalhistory/documents/nehring_un_sources.doc.

${ }_{53}$ www.jstor.org, accessed through the Harvard University Library, i9 October 2007.

54 "Remarks Upon Laying the Cornerstone of the National Archives Building," 20 February 1933, in Public Papers of the Presidents of the United States, Herbert Hoover (1932-33) (Washington, D.C.: Government Printing Office, I977), p. 47I.

55 Speech of Montalivet on 15 August $18 \mathrm{I}_{2}$, in Bordier, Les Archives de la France, p. 28. 
ereignty and also for techniques of public administration. ${ }^{56}$ The great reforms of public administration in the nineteenth and early twentieth centuries had two principal components, having to do with the creation of a civil service and the institutionalization of administrative records. The independence of the international civil service was one of the most important achievements in the political history of the UN, under Dag Hammarskjöld's secretary-generalship. ${ }^{57}$ The institutionalization of international public records is still incomplete, and "one of the troubles with the UN," in the expression of Hammarskjöld's colleague and biographer Brian Urquhart, "is the fact that it never had a historical section." 58 "Good government is not a theoretical concept," Pino Akotia of the University of Ghana wrote in the final issue of the international archivists' journal Archivum, and the "ability of the state to manage recorded evidence of the conduct of government business is perhaps the most basic of all." ${ }^{59}$ This is true of public institutions that are not states, as well..$^{60}$

Archives and records are of administrative importance, above all, because of their relationship to transparency and accountability. UN agencies are the object of scrutiny by the news media, by governments, by commissions and committees, and, eventually, by scholars, or by the verdict of history, with which presidents (and secretaries-general) are said to be so preoccupied. Anthony Grafton concluded his history of the footnote with the affirmation that "only the use of footnotes and the research techniques associated with them makes it possible to resist the efforts of modern governments, tyrannical and democratic alike, to conceal the compromises they have made, the deaths they have caused, the tortures they or their allies have inflicted." ${ }^{61}$ The UN and its agencies are not governments. But they too have made compromises; their point, in a sense, is to make compromises instead of causing deaths, and

56 Posner, "Effects of Changes of Sovereignty," pp. r68-r69.

57 See "Subversives in the UN: The World Organization as an Employer," Stanford Law Review 5, no. 4 (1953): 769-782; and Mark W. Zacher, Dag Hammarskjold's United Nations (New York: Columbia University Press, I970), pp. 39-47.

58 Quoted in UN Voices: The Struggle for Development and Social Justice, ed. Thomas G. Weiss, Tatiana Carayannis, Louis Emmerij, and Richard Jolly (Bloomington: Indiana University Press, 2005), p. I62.

59 Pino Akotia, "Managing Public Sector Financial Records for Good Government in Sub-Saharan Africa," Archivum 45 (2000): 97-I I 7, I I 2.

60 On the UN's use of information, see the Report of the Panel on United Nations Peace Operations, chaired by Lakhdar Brahimi, August 2000, http://www.un.org/peace/ reports/peace_operations/.

61 Anthony Grafton, The Footnote: A Curious History (Cambridge, Mass.: Harvard University Press, I999), p. 233. 
they, too, are accountable to the research of the press, and of scholars. The "democratization" of international public records that was such a conspicuous objective in the projects of the I940s and early I950s, the "ready" and "equal" access to scholars (or journalists) "of all countries," is still a distant hope.

There is a different and more novel reason, too, for the special importance of international archives to international institutions. The modern world, Charles Braibant of the Archives de France wrote in I95I, was at risk of "drowning in the documentary ocean which is submerging it." 62 The documentary ocean is now an entire biosphere of images and words. But the UN and its constituent entities are of all the political or quasi-political institutions of these modern times, the most profoundly virtual - the most purely places of images, words, and precedents.

"In modern societies, stretched over vaster territories and far more diverse citizenries, a politics stripped of powerfully expansive words is virtually inconceivable," Daniel Rodgers has written of American political life. It is words that "unify and mobilize" and words that make sense out of policy and power: "the superimposition of some believable sense and endurable legitimacy on top of the chaotic motions of day-to-day power." This government of rhetoric, this "appetite for powerfully resonant and powerfully abstract words," is characteristically American, as Rodgers suggested. ${ }^{63}$ But it is also characteristic of almost all the politics of the late twentieth century, and especially of the politics of the UN (which was itself, in a cultural or cultural-political sense, an idiosyncratically American institution, established, against the wishes of Dean Acheson and others, in the cultural and media capital of American politics). The "day-to-day power" of the UN was constituted by words, or by the superimposition of credibility and legitimacy. It had no enduring sources of revenue, or military forces, or powers of coercion; it was a power of abstraction, or a "government of words." ${ }^{64}$ The UN with its funds and missions is now a large, complicated economic organization, which buys generator sets and catering services and contraceptives, "buying" and "shopping" for goods and services to the value of \$ 59 million in the Democratic Republic of Congo in 2006, or \$208 million

${ }^{62}$ Charles Braibant, "Archivum," p. 3.

${ }^{63}$ Daniel T. Rodgers, Contested Truths: Keywords in American Politics since Independence (Cambridge, Mass.: Harvard University Press, I998), pp. 4-5, 7.

${ }^{64}$ The phrase "government of words" was used by Washington Irving in 1807 , of the government of the United States; quoted in Rodgers, Contested Truths, p. 7 . 
for the UN "Population Fund." ${ }^{65}$ But its contracts, far more than the contracts of national governments, ebb and flow with campaigns, or with the concluding documents of conferences.

The idea of international institutions as places or palaces of language was as old as the fantasies of internationalism of the early twentieth century. The world organization for energy conservation, or the "suppressed world conscience" that H. G. Wells imagined in The Secret Places of the Heart, was to be a place, above all, of "say": "I want to get the beginnings, the germ, of a world administration. I want to set up a permanent world commission of scientific men and economistswith powers, just as considerable powers as I can give them-they'll be feeble powers at the best-but still some sort of say in the whole fuel supply of the world. A say-that may grow at last to a control. A right to collect reports and receive accounts for example, to begin with. And then the right to make recommendations ... You see?... No, the international part is not the most difficult part of it." ${ }^{66}$ In the new UN institutions of the I940s and I950s, these rights in respect to reports and statistics were embodied in powers of information-reports on malaria, infant mortality, population growth, torture, and human rights. There were commissions of "scientific men," and there was also a new ideology of international public opinion or public information. The "annual report" became a characteristic form of expression, from the "Annual Report from Palestine" produced by the UN Palestine Commission starting in I 945 to the "preliminary exposé" of an annual report on "International Folk Music" that UNESCO published in I 953.67 "UNESCO will know how to fulfill its mission of a spiritual link between nations," the Brazilian delegate declared at a meeting in

65 Procurement statistics for 2006 available at http://www.un.org/Depts/ptd/o6com5o .htm, and http://www.unfpa.org/procurement/statistics.htm. On "Buying for a Better World" and "UN Web Buy," see http://www.iapso.org/information/publications.aspt; and on the UN Population Fund (UNFPA) and its policies- "shopping is a procurement method based on comparing price quotations obtained from several suppliers,"- see http://www.unfpa.org/ procurement/methods.htm. All Web sites accessed on 20 October 2007.

${ }^{66}$ H. G. Wells, The Secret Places of the Heart (New York: Macmillan, I922), pp. 88, 90. The speaker is Sir Richmond Hardy, an owner of coal mines, much exercised by the extent to which "all the world is wasting fuel-fantastically": "If we set about getting fuel sanely, if we do it as the deliberate, co-operative act of the whole species, then it follows that we shall look very closely into the use that is being made of it. When all the fuel getting is brought into one view as a common interest, then it follows that all the fuel burning will be brought into one view .... I want to get the whole business of the world's fuel discussed and reported upon as one affair-so that some day it may be handled as one affair-in the general interest" (pp. 84-85, 87).

67 "Folk music can constitute a bond of union between people of all levels of culture... it should serve to lessen the gap between the music of the 'highbrows' and the 'lowbrows'”: 
November 1946, chaired by Léon Blum; "an international public opinion inspired by UNESCO will spring into existence." 68

The individuals who were most involved in the early UN were intensely conscious of the power of international words and images, and of the transitoriness of legitimacy. Even the earliest UN flags, and the "light blue" that has been the UN's color since I947, were an aspiration to "dignity." ${ }^{6}$ The national delegations were meanwhile at a loss, often, as to how to adapt to the new international politics of public opinion. The Trusteeship Council, one British official reported in the summer of 1945 , had been held up by "the failure of the Russians to get a reply from Moscow about the word 'independence," as well as by "Iraqi anxieties about Palestine." Another official warned that "unless we make some concessions to the prevailing thirst for slogans of all kinds we should risk falling behind the Americans in the race for 'moral leadership." Yet another official, a "Miss Wilkinson," "deplored the fact that the proceedings at the Plenary Session on the previous day which had had the character of a horse-deal should have been represented as conceding to M. Molotov the fruits of moral leadership." 70

The "prevailing thirst for slogans of all kinds" was transposed, in the later history of the UN, into an organizing principle of the social, economic, and environmental agencies that are grouped together by Paul Kennedy as the "UN's soft agendas" "11: the United Nations Environment Program and the Stockholm Conference of 1972, the Food and Agriculture Organization and the World Food Conference of I 974, and the Rio Conference on Environment and Development. A large

\footnotetext{
"Preliminary Exposé on the Role of Folk Music in Education, based on the Report of the Fifth Annual Conference of the International Folk Music Council," UNESCO/CUA/MEı 3,26 June I953, available at http://unesdoc.unesco.org/images/oo I4/oor 439/14390 I eb.pdf. UN Palestine Commission, "Annual Report from Palestine," I January I 945 to 22 March I948, "WebDrawer-Archival Folder-S-o6I4-00oI-08-Archival Folder Identification," cited at http://archives-trim.un.org/webdrawer/rec/288 I I I /.

${ }_{68}$ Remarks of M. Moniz de Aragao (Brazil), 2 I November 1946, in General Conference, First Session (UNESCO, I947), p. 33, available at http://unesdoc.unesco.org/images/oor I/ oo I I 45/I I 458oEb.pdf.

69 The early uses of the UN flag were thus in Greece: "Recently, for example, in order that the Commission of Investigation concerning Greek Frontier Incidents might enjoy the protection of and be identified by a neutral symbol while travelling through troubled areas or sitting in meetings under the jurisdiction of several countries, an unoffical flag was designed by the Secretariat"; the Secretary-General proposed a draft resolution which authorized him "to adopt a flag code, having in mind the desirability of a restrictive use of the flag and the protection of its dignity." "A Flag for the United Nations," United Nations General Assembly, A/342, 2 I August I947, available at http://unbisnet.un.org/, or http:// daccessdds.un.org/doc/UNDOC/GEN/NL4/700/I 5/PDF/NL4700 I 5.pdf?OpenElement.

70 Record of the United Kingdom Delegation, I May I945, p. 2, I 9 May I 945, p. 2 , 29 May I945, p. 6, TNA, CAB 2I/I6I I.

${ }^{71}$ Kennedy, Parliament of Man, p. I 76.
} 
part of the UN's activities has been a matter of conferences, reports, and big, impractical expressions. "Sustainable development," "common security," and the "Human Development Report" have played something of the role, in this new international quasi-politics, of the "big, impractical words" that Daniel Rodgers described in American political life. ${ }^{72}$ They are successful words, by the competitive criteria of the new international-transnational society, mentioned in some $38,000,000$ Web pages in the case of "sustainable development," or some I,490,000 for "Human Development Report." 73 Their position is one to which other words aspire. As the advisers to a Japanese-supported fund concerned with "human security" lamented in 2003, "While the concept has begun to permeate UN organisations and member states, human security has not yet become a formal 'UN word.'"74

The provision of information was in a more profound sense at the very heart of the UN's political role or roles, for the "legitimacy" of the $\mathrm{UN}$ is also a matter of its "legality," or its position in internationaltransnational law. ${ }^{75}$ Its legality, in turn, is a matter of published or publicly available legal words. The legitimacy of the UN has been a preoccupation in moments of high political drama-the invasion of Iraq in March 2003 was described by the UN secretary-general as "a sad day for the United Nations," in a time when "the peoples of the world have shown what great importance they attach to the legitimacy conveyed by the authority of the United Nations"-and it is also the cumulative outcome of public information about the law, in innumerable reports and series and digests. ${ }^{76}$

The "annual digests and reports of public international law cases" with which the UN has been so involved since the r940s are in this

72 Rodgers, Contested Truths, p. 7 .

73 Web search on 20 October 2007.

${ }^{74}$ Minutes to the Ist Meeting of the Advisory Board on Human Security, I6-I 7 September 2003, available at http://www.humansecurity-chs.org/abhs/Boardmeetings; and see Emma Rothschild, "The Age of Words: Histories of Human Security" (in Japanese) in Human Security, ed. Yusuke Dan (Tokyo, 2006).

75 On the relationship of international institutions, including the International Court of Justice, to "legality and legitimacy," and to the constitutionality of the acts of international organizations, see Hisashi Owada, "The United Nations and the Maintenance of International Peace and Security: The Current Debate in the Light of Reform Proposals," Keynote Speech at the Research Forum on International Law, European Society of International Law/Graduate Institute of International Studies, 26 May 2005.

${ }^{76}$ United Nations Press Release, SG/SM/8644 (20 March 2003). The French minister of foreign affairs, Dominique de Villepin, also referred to the legitimacy of the UN, which he described as "the place where international rules and legitimacy were founded," United Nations Press Release SC/7696 (ig March 2003); available at http://www.un.org/News/ Press/docs/2003/sgsm8644.doc.htm and http:/www.un.org/News/Press/docs/2003/sc7696.doc .htm. 
sense of political as well as legal importance. ${ }^{77}$ The "tremendous quantity" of documents from the UN and multiple other international legal sources was widely discussed in the early i 960 , at a time when international law was considered to be of unprecedented interest to the "public mind." 78 The accessibility of these sources at a period of continuing interest in the relationships between individuals and international law-and when the universe of potentially relevant legal sources has multiplied far beyond the imagination of the r96os-is again a matter of political interest, the politics of equal access to the law. The dissemination of printed case records in North America in the very early nineteenth century had profound consequences, it has been argued, for the development of "a state-centered, self-conscious legal culture." 79 Access to information about international legal sources, and to the capacities for making sense of the information, may play a comparable role, eventually, in the development of a worldwide legal culture.

The archives of the UN are important, for all these reasons, to the new politics of international organizations, and even to the politics of internationalism. They are also important, finally and most obviously, to the "new UN history" that is represented in this issue, as in Sunil Amrith's work on public health, Carol Anderson's on race in the I950s, Matthew Connelly's on population policies, and Mark Mazower's on the origins of the modern rhetoric of human rights. ${ }^{80}$ The new history is very different, in prospect, from the history of the officials who exemplified the difficulties of international records for the archivists of I944, the experts on cabinet minutes who attended so many international meetings and whose papers were to be found in so many repositories. But it is a history that imposes its own difficulties of records and its own archival odysseys.

77 See, for example, Herschel Lauterpacht, Annual Digest and Reports of Public International Law Cases, Being a Selection from the Decisions of International and National Courts and Tribunals and Military Courts during the Year 1949 (UNESCO, I955); available at http:// unesdoc.unesco.org/images/oor 4/oor 439/14390 r eb.pdf.

78 Carl B. Spaeth, "International Legal Materials," Stanford Law Review i6, no. I (1963): 229-234, 230.

${ }_{79}$ Hendrik Hartog, "Distancing Oneself from the Eighteenth Century: A Commentary on Changing Patterns of American Legal History," in Law in the American Revolution and Revolution in the Law, ed. Hartog (New York: New York University Press, I981), pp. $229-257,255$.

80 Sunil Amrith, Decolonizing International Health: India and Southeast Asia, 1930-65 (London, 2006); Carol Anderson, Eyes off the Prize: The United Nations and the African American Struggle for Human Rights, I944-I955 (Cambridge: Cambridge University Press, 2003); Matthew Connelly, "Seeing beyond the State: The Population Control Movement and the Problem of Sovereignty," Past and Present, no. 193 (November 2006): 197-233; and Mark Mazower, "The Strange Triumph of Human Rights I933-1950," Historical Journal 47, no. 2 (2004): 379-398. 
The history of the UN's agencies, palaces, and missions as sites of international or long-distance or transnational exchange; the history of UN institutions as a diverse collection of individual officials, nurses, soldiers, and vaccination technicians, or of the "subaltern" and feminized UN of the later twentieth century; the history of the languages, translations, and figures of speech of international institutions; the history of the political exchanges in and around the $\mathrm{UN}$ as an incipient transnational politics, which is pluralistic but undemocratic, in Matthew Connelly's sense, and is also a politics of words, in Daniel Rodgers's sense: all of these "new histories" require archives, which are international archives. ${ }^{81}$ The sources and archives for the new UN history are far more disparate than the administrative records that were the principal object of the US archivists' proposal of October I945. They are more disparate, even, than the documents to which Ernst Posner looked forward in his visionary observation of 1942 , about the ever-widening extension of "the dignity of source materials of history." But they include - and require-the old administrative records: the records of the UN Palestine Commission, or the Trusteeship Council, or the "Stockholm Conference."

These records and archives of international administration are sensationally unromantic in the nineteenth-century historians' sense, or Ranke's sense, of documents in archives as "so many princesses, possibly beautiful, all under a curse and needing to be saved." 82 They have very little of the twentieth-century historians' sensuousness of archives,

${ }^{81}$ On sites of international exchange, see Jean-Claude Pallas, Histoire et Architecture du Palais des Nations I 924-200 I (Geneva: United Nations, 200I); on UN history from below, see Amrith, Decolonizing International Health; and on pluralistic and democratic world politics, see Connelly, "Seeing Beyond the State," p. 233. The crisis at UNESCO over the resignation in 1952 of Torrès-Bodet, the second director-general and the patron of archival internationalism, was itself an interesting illustration of the UN's multiple uses of language. The French delegate said that the departure of Torrès-Bodet, with "his profound knowledge of our language," plunged the entire French nation "into affliction"; the delegate of Lebanon said on behalf of all the delegations of Arab states, as well as "the Middle East and Iran," that "for once it is not a figure of speech to say to you that emotion prevents us from speaking"; Jean Piaget wept in asking for a reconsideration of the UNESCO budget; the British delegate, much disturbed by the presence of "emotional extremists such as Piaget," described a speech by the Brazilian presiding officer that was "translated from the Portuguese original produced by Carneiro into French, and then into English with the result that it read rather like a tribute from the faithful to Stalin." UNESCO General Conference, 26 November 1952, 7C/VR. 7 (prov.), "Blind Cuts in UNESCO Budget," Manchester Guardian, 29 November 1952, Telegram no. 479 from Sir O. Harvey of 26 November 1952; all in TNA, $\mathrm{FO}_{371 / 101529 .}$

${ }^{82}$ Letter of 6 February 1828 from Leopold von Ranke to Bettina von Arnim, quoted in Bonnie G. Smith, "Gender and the Practices of Scientific History: The Seminar and Archival Research in the Nineteenth Century," American Historical Review Ioo, no. 4 (I995): I I 50-I I 76 , I I65. 
very little of the disorientation, the "suspended state of impressionability" into which historians enter, in entering into the lives of other people. ${ }^{83}$ The archives of international organizations look like conference rooms, or depositories of commission reports, or screens full of sentences. "In a memorandum laid before us by the Technical SubCommittee there is a sentence which sounds like a sigh," a Danish delegate said in the UNESCO meeting of 1946, the meeting at which the Brazilian delegate spoke about international public opinion (and the delegate of China about a common heritage of the mind, "we in the Orient, as the honorable delegate of India has emphasised, value quality"). ${ }^{84}$ The archives of the UN are full of sentences that sound like sighs. But so too is the real world of internationalism.

The early twenty-first century is a difficult time for archivists and archives almost everywhere, and also a time of opportunity. No archivist and no "record section," in the public or the private sector, could be confident in the face of the new technologies of communication. The technologies of conservation, including digitization, are also new, and the conservation of digital records is itself the subject of intense concern. Private collections, especially in Africa and inner Asia, are in particularly imminent danger. ${ }^{85}$ Even some of the oldest established national archives have been the subject, in recent years, of what historians, even in Italy and France, have described as a combination of neglect and political anxiety. ${ }^{86}$

At least some of these quite general difficulties are particularly serious for the archives of the UN system. The directors of the UN Intellectual History Project, based at the City University of New York, wrote to the secretary-general of the UN in November 2005 that "records at the moment are very inadequately preserved, especially across different parts of the UN," for reasons of "endless pressure on finances, the lack of interest by many governments, the recent switch from paper to electronic communication and, in some cases, the fear that witch hunts may concentrate more on digging up dirt than learning lessons

${ }^{83}$ Christine Stansell, "Dreams," History Workshop Journal no. 62 (2006): 24 I-252.

${ }^{84}$ Remarks of Dr. Yuen Ren Chao (China) and M. Nielsen (Denmark), 2 I November I946, in General Conference, First Session, pp. 33, 36, available at http://unesdoc.unesco .org/images/oo I I/oo I I 45/ I I 4580Eb.pdf.

85 See "The Threat to Archives," The Endangered Archive Programme, http://www .bl.uk/about/policies/endangeredarch/threat.html.

86 See Marc-Olivier Baruch and Vincent Duclert, "Archives nationales à l'abandon," Le Monde, I I-I2 September 2005, p. I2; and Claudio Pavone, "Il nuovo custode della memoria: Il governo e la legge sui poteri archivistici di Palazzo Chigi," La Repubblica, 26 August 2005, p. 50. 
for the future." ${ }^{87}$ This is a harsh evaluation, and a number of archives within the UN have undertaken outstanding projects of digitization: the papers of UN Secretary-General U Thant, for example, which are available on the Web site of the UN Archives and Records Management Section (UNARMS) and the UNESCO documents available on the Web site of UNESCO's own archives. ${ }^{88}$ There are guides to using the archives of UN and other international organizations on the Web sites of the International Council on Archives and on the UNESCO Archives Portal-a universal archive of access to archives. ${ }^{89}$ The UN Archives have produced new policies about "removing records upon separation from service" and a remarkable "record keeping toolkit for peacekeeping operations"- "human trafficking detection and identification .. . Must Not Destroy." 90

There is even something of the historians' sublime in U Thant's files concerned with the worldwide public and the escalation of the Vietnam War in 1965 , or in the sentence like a sigh of 1946 . One of the archivists' preoccupations, in their mid twentieth-century world of internationalism, was with the "frontiers of archivism," and the place, within archives, of things which were not two-dimensional, or written, or "clothed in writing" ("revêtu de l'écriture"). ${ }^{91}$ The correspondence files of $U$ Thant are an eclectic collection of typewritten, handwritten, and printed writings, and the UNESCO documents a compendium of mimeographed resolutions, conference reports, and publications in various languages-written things. But the UNARMS and UNESCO digitization projects provide a view of these collections that is extraordinary, not only because it is available (without charge) to everyone, everywhere, but also because it offers the possibility of looking for words

${ }^{87}$ Letter of November 2005 from Richard Jolly and Thomas G. Weiss to Kofi Annan, on behalf of a group of scholars and archivists who met at the Institute of Commonwealth Studies in London in October 2005. I am grateful to Professor Thomas G. Weiss, City University of New York, for providing me with a copy of the letter. Further information about the UN Intellectual History Project is available at www.unhistory.org. .shtml.

${ }^{88}$ See http://archives-trim.un.org/ and http://unesdoc.unesco.org/ulis/search_form

${ }^{89}$ See http://www.unesco.org/archives/sio/guide/uk/sommaire.html, and http://www .unesco.org/cgi-bin/webworld/portal_archives/cgi/page.cgi?g=Archives\%2FGovernment \%2FInternational\%2FIntergovernmental_Organizations\%2FUN_System \%2Findex .shtml; $\mathrm{d}=\mathrm{I}$, accessed on $2 \mathrm{I}$ October 2007.

90 See http://archives.un.org/unarms/index.html, http://archives.un.org/unarms/en/ unrecordsmgmt/unrecordsresources/recordkptoolkitpeacemiss.html, and http://archives.un .org/unarms/doc/retentionschedules/Human\%2oRights.pdf, accessed on 2 I October 2007.

${ }_{91}$ Direction des Archives de France, Le Concept d'Archives et les Frontières de l'Archivistique: Actes de la Septième Conférence de la Table Ronde Internationale des Archives (Paris: Archives Nationales, 1963), p. 25. 
and names and ideas in so many different kinds of writing — a bird's eye view, or a magpie's view, of international exchange. ${ }^{92}$

The endless pressure on resources is undoubtedly daunting, in respect to these projects and others. There is an evident responsibility for the governments and private organizations who pay for the UN-who have an "immense stake" in the institution, in the language of I945, and thereby in "the fate of civilization itself"- to take seriously the archives and the evidence of international cooperation. But there is a responsibility, too, for historians, for the difficulties of the UN archives are in part the difficulties of not being used, of not being importuned by the various "users," historians and others, who are so important to the most resilient of the national archives. In the extended recent discussions of the historiography of the "transnational turn," there has been oddly little interest in the archives of international or transnational history, or in the more portentous questions, the questions raised by the archivists (who were also historians) of 1945, of what it is for an archive to be international. ${ }^{93}$ The sense of an "isomorphism" of archives and objects of historical investigation - that local history requires little archives, national history requires national archives, and international or world history requires gigantic archives, the archives of 18 I $_{2}$ or 1945 -is now counterintuitive. There is a micro-history of worldwide connections (the connections within families, for example) and a global history of localities (provinces and the distant scenes to which they were connected by commerce, commodities, or emigration) - a variable geometry of archives. But the US archivist's impolite question of I946, about whether scholarship that is based on the archival resources of a single country is "one-sided and nationalistic,"

92 See, for example, on the Vietnam war, "Items-in-Peace-keeping operations-Vietnam-communications from the general public — correspondence from general public" ( 26 February 1965), "Items-in-Peace-keeping operations-Vietnam-Secretary-General-personal and confidential" (I June I965), WebDrawer Archival Items S-o87I-0005-05-I and S-o866-0ooI-07-I, available at http://archives-trim.un.org/webdrawer/rec/423867, and http://archives-trim.un.org/webdrawer/rec/423199. The digital records can be searched via the advanced search form available at http://archives-trim.un.org/, using the title word "Thant" and identifying "document content" as the domain in which the search term is to be found. The UNESCO digital documents can be searched via http://unesdoc.unesco .org/ulis/search_form.shtml. The Anthony Eden papers, which have been digitized by the National Archives of the United Kingdom, are by contrast available online without charge only to academic users associated with the UK's academic access portal; see http://www .nationalarchives.gov.uk/documentsonline/search-results.asp?CatID $=\mathrm{I} 7 \&$ search Type $=$ bro wsable\&pagenumber $=\mathrm{I}$ \&query $=*$ \&queryType $=\mathrm{I}$. Web sites accessed on 2 I October 2007.

${ }_{93}$ For interesting observations on the archives of transnational history, see the comments of Matthew Connelly in "AHR Conversation: On Transnational History." 
is still of interest. So is the related question about scholarship that is based only on public or official archives, the archives of "states" and not of "society."

The responsibility is connected, in the end, to something even more general, which is the romance between the historian and her sources. I hope I have been able to suggest that the history of the UN's archives, or of the UN's involvement with archives, is itself interesting, and even inspiring. There have been remarkable recent investigations of the history of other archives, national and international. ${ }^{94}$ But there seems to be something about how historians work-some "ironical self-consciousness," in Nietzsche's expression, or some revulsion, also described by Nietzsche, for the conservationism in which "the soul is rather possessed by the furniture" - that has contributed to a relatively large distance, in recent years, between the anxieties of historians and the anxieties of archivists. ${ }^{95}$ This is a loss, in the sense that the history of archives is so interesting. It is a loss, too, in the sense that the questions with which archivists, "the passive warehousemen of history" in the expression of $195 \mathrm{I}$, are concerned are of such momentous importance, even to historians.

The digitization of history in which historians are now so involved is itself the outcome of the archivists' dramas of the mid twentieth century. The microfilms made in the age of "massive and systematic" duplication are the images that have been digitized, in many cases; the questions over which the archivists argued and shuddered, of the loss of control and the loss of contact, the microfilm of substitution and the microfilm of security, the understanding of property rights in historical documents, are the questions, or very close to the questions, of our own times. ${ }^{96}$ But the old discussions were far more international, in an odd respect, or more universal, than the discussions now. The transforma-

${ }^{94}$ See, for example, the project "Opening up the Archives" organized by Ann Blair and Jennifer Milligan in April 2006, http://www.radcliffe.edu/research/archives/; or the series of reports on archives published in History Workshop Journal; or the work of the International Conferences on the History of Records and Archives, http://www3.fis.utoronto.ca/research/ i-chora.

${ }_{95}$ Friedrich Nietzsche, On the Advantage and Disadvantage of History for Life (1874), trans. Peter Preuss (Indianapolis: Hackett Publishing Company, I980), pp. I9, 43.

96 "In the United States it is believed that archives are the property of Humanity," Ernst Posner said at the archivists' meeting in Warsaw in I96r. First Working Session, "Problèmes posés par le microfilmage en pays étranger," in Les Archives dans la Vie Internationale, pp. I 24-I 28, I 24, I 26. For references to continuing discussions of the digitization of history in relation to transnational or international history, see http://www.fas.harvard.edu/ histecon/ research/digitization.htm. 
tion that is under way in the possibilities and the aesthetic experience of historical research has profound consequences for the distribution of historical understanding: across the history of different countries and societies, in different languages, and by individuals within (or outside) different academic institutions. It has particular consequences for historians of international or global connections. It is a transformation in which the international institutions, and their own histories, are of enduring importance.

The archivists of the I940s and I950s used the idea of democratization in two different senses in their writings on international archives: of the new council of archivists as an association of individuals and not of nations, and of the new technologies of very large-scale microfilming and duplication as a "democratization of the archival reference service"- "a final break with the archivist's proprietary attitude towards his records." 97 The break with the archivist's propriety, which is now on a vastly larger scale, is also a break with the propriety of historians. It is a democratization of history, in prospect, and an internationalization of historical sources. It is a reason, at least, to revisit the grand and Rankean words of Jaime Torrès-Bodet of UNESCO in I950, to the Assemblée constituante du Conseil international des Archives, that archives are the source of stories that are true, for those who use them "with an open spirit, capable at the same time of objectivity and imagination, to represent the past as it really was." 98

97 Posner, "The National Archives and the Archival Theorist," p. I35.

98 "L'Assemblée Constituante du Conseil International des Archives," p. 26. 